\title{
A Contribution to the Aetiology of the Congelation of the Auricle.
}

\author{
By \\ Mitsuaki Sayama. \\ From the Otological Clinic of the Kyoto Imperial University Hospital.
}

(Prof. T. Hoshino).

It is a fact widely known, that the auricle has great disposition to congelation ranging from serious necrosis to mere frost-bite, the latter being met with even in temperature of more than $0^{\circ} \mathrm{C} .\left(32^{\circ} \mathrm{F}\right.$.) This is, aside from individual dispositions, such as, personal resistance, age, nutritive condition, circular disterbance, blooddiseases, professional disposition as in outdoor labourers, due to the anatomical characteristics of the auricle, that is,

1. The thinness of the skin,

2. Slight amount of subcutaneous tissue,

3. Exposure to the open air,

4. Absence of movements of its own.

Being subjected to the natural law, it is no wonder that the congelation of the auricle varies in its grades in accordance with the manner, duration, and power of the attack of coldness. The dominant factor here, nevertheless, is cold itself. The auricle is characterized by its uneven surface with many foldings, and in consequence, as one easily understands, the surface in question is far larger relatively to its volume than any other parts of the human body, even the finger, the toe, and the nose holding only three surfaces for one volume. The fact that the radiating surface of the auricle is very large, might be of much significance to the aetiology of the freezing of the auricle. Anybody might have thought of this, but no one has yet solved this problem with exact figures. To fill up this blank space of our literature, the author has succeeded in surveying the surface of the auricle. As the methods of measuring the body-surface hitherto published, are neither all available nor perfect in surveyance of the ear-surface, because the auricle is very liable to give way to even a slight touch changing its form and the tension of its skin in a considerable degree. To overcome these hinderances, the author has 
worked out his new method.

At first, the impression of the auricle is taken with the plaster of Paris used in dentistry, the precautions being taken not to let it adhere to the skin and to carefully separate it along the convex side of the Helix in two peices, one anterior and one posterior. For the separating material, vaselin or olive oil is used. Being taken off from the auricle in two peices, the negative pattern is set together againnegative auricle.

The volume of the auricle is easily found out by reading the scale of the measuring cylinder into which the water, with which the negative mould has been filled up, is empted, vaselin being slightly smeared beforehand on the impression in order to keep out a possible leakage and absorption of water.

The surface of the auricle measured as follows. The negative auricle is separated in two peices. The surface of each peice is vaselined, and covered up with a single layer of the finest shot (Size No. 1.). If the overhanging parts of the negative which correspond to the cavities of the auricle, such as Cymba conchae and Scapha, come in the way, they may be broken off with the fingers and each peice treated separately in the same manner as above described, the broken surface, of course, being excluded. The total number of shot used, is now balanced. From this weight the whole surface is easily calculated out of the averaged weight of the slug-layer in one square centimetre.

The surface of the auricle to be measured is limited, in the present work, anteriorily by the line connecting the upper and lower ends of the insertion of the auricle, posteriorily with the insertion line of the auricle and from the external meatus with the niveau of Cavum conchae.

The following is the result of the auricular surveyance after the author's new method. The auricles measured, are those of males and females of various ages, ranging from seven years old to sixty-three. 


\begin{tabular}{|c|c|c|c|c|c|c|c|c|c|}
\hline & \multirow{2}{*}{ Name } & \multirow{2}{*}{ Sex } & \multirow{2}{*}{ Age } & \multicolumn{2}{|c|}{ Vol. (c.c.) } & \multicolumn{2}{|c|}{ Surf. (sq. c.) } & \multicolumn{2}{|c|}{ Ratio } \\
\hline & & & & Left & Ri rht & Left & Right & Left & Right \\
\hline 1 & Y. S. & Female & 7 & 7.2 & 7.0 & 35.0 & 34.3 & 4.9 & 4.9 \\
\hline 2 & O. G. & Male & 7 & 7.5 & 8.0 & 42.9 & 41.5 & 5.8 & 5) 2 \\
\hline 3 & T. $\mathrm{S}$ & Female & 8 & 5.7 & 5.7 & 32.3 & 42.9 & 5.7 & 7.2 \\
\hline 4 & s. s. & Male & 14 & 6.1 & 6.0 & 42.9 & 44.3 & 7.0 & 7.4 \\
\hline 5 & $\mathrm{Y} . \mathrm{Y}$. & $"$ & 16 & 7.4 & 7.6 & 44.3 & 44.9 & 6.0 & 5.6 \\
\hline 6 & N. C. & Fernale & 16 & 7.5 & 7,7 & 39.3 & 37.1 & 5.2 & 5.0 \\
\hline 7 & M. s. & Male & 16 & 6.9 & 6.0 & 46.2 & 47.3 & 6.7 & 7.9 \\
\hline 8 & H. H. & " & 16 & 8.9 & 8.9 & 48.6 & 51.4 & 5.5 & 5.8 \\
\hline 9 & ' $\mathrm{l} . \mathrm{M}$. & Fernale & 17 & 8.0 & 7.6 & 44.3 & 42.9 & 5.5 & 5.6 \\
\hline 10 & T. K. & Male & 17 & 7.2 & 7.1 & 47.1 & 41.5 & 6.5 & 5.8 \\
\hline 11 & K. Y. & Female & 18 & 10.0 & 11.0 & 47.1 & 47.1 & 4.7 & 4.3 \\
\hline 12 & M. $\mathrm{s}$. & Male & 19 & 7.9 & 80 & 42.9 & 44.3 & 5.4 & 5.5 \\
\hline 13 & I. M. & $"$ & 20 & 10.0 & 10.0 & 51.4 & 48.6 & 5.1 & 4.9 \\
\hline 14 & Y. K. & " & 21 & 10.0 & 10.0 & 50.9 & 52.4 & 5.1 & 5.2 \\
\hline 15 & T. $\mathrm{H}$ & Female & 22 & 7.5 & 8.5 & 39.0 & 429 & 5.0 & 4.6 \\
\hline 16 & M. S. & Male & 23 & 8.8 & 8.6 & 45.7 & 46.4 & 5.2 & 54 \\
\hline 17 & N. M. & $"$ & 24 & 7.0 & 7.3 & 44.3 & 40.0 & 6.3 & 5.4 \\
\hline 18 & F. K. & $"$ & 29 & 9.0 & 7.9 & 46.4 & 44.3 & 5.2 & 5.6 \\
\hline 19 & K. Y. & $"$ & 30 & 6.7 & 6.5 & 42.9 & 44.3 & 6.4 & 6.9 \\
\hline 20 & N. I. & Female & 30 & 8.6 & 8.2 & 48.0 & 47.0 & 5.5 & 5.7 \\
\hline 21 & M. Y. & Male & 30 & 7.0 & 6.8 & 40.9 & 41.2 & 5.9 & 6.0 \\
\hline 22 & K. S. & Female & 30 & 9.0 & 9.2 & 40.7 & 48.6 & 4.5 & 4.7 \\
\hline 23 & Y. K. & Male & 33 & 11.0 & 10.0 & 50.0 & 47.0 & 4.5 & 4.7 \\
\hline 24 & N. K. & $"$ & 35 & 8.0 & 8.2 & 50.0 & 45.0 & 6.2 & 5.5 \\
\hline 25 & S. T. & $"$ & 36 & 6.5 & 5.5 & 42.9 & 42.9 & 6.6 & 7.8 \\
\hline 26 & S. K. & Female & 40 & 8.0 & 8.2 & 40.0 & 35.7 & 5.0 & 4.4 \\
\hline 27 & M. M. & " & 42 & 8.5 & 8.1 & 48.0 & 44.4 & 5.7 & 5.5 \\
\hline 28 & K. T. & Male & 43 & 9.1 & 8.8 & 42.9 & 42.1 & 4.7 & 4.7 \\
\hline 29 & H. T. & " & 49 & 11.0 & 11.8 & 52.1 & 52.9 & 4.7 & 4.7 \\
\hline 30 & N. K. & $"$ & 60 & 10.5 & 9.9 & 55.0 & 55.0 & 5.2 & 5.0 \\
\hline
\end{tabular}

To summarize :

The surface of the auricle is far larger in relation to its volume than other parts of the human body, ranging from five to eight square centimetres for one cubic centimetre of volume. The relation above mentioned is independent of age, sex and the side to which the auricle belongs. The author's method might be better fitted than others ever published to take the measurment of the surface of 
casily flexible and uneven objects, the process being relatively easy and simple. To make things still better, the error brought by the changes of the tension of the skin are excluded.

\section{Bibliography.}

1. Tehrbuch u. Atlas d. Ohrenheilk. by Gustav Brühl, 1913, p. $233 . \quad$ 2. Die Krankheit d. Ohres, by Arthur Hartmann, 1908 , p. 97 3. Lehrbuch d. Ohrenheilk. by G. Bönninghaus, 1908, p. 119. 4. Kompendium d. Ohrenheilk. by H. Schröder, 1896 , p. 53. 5. Lehrbuch d. Ohrenheilk. by Politzer, 1908, p. 180.

6. Lehrbuch d. Ohren-, Nascn-u. Kehlkopfkrh. by Körner, p. 394.

7. Handbuch. d. Ohrenheilk. by W. Kircher, 1904, p. 42. 8. Die Verletzungen d. Gehörorgans, by Passaw, 1905, p. 1, p. 8. 9. Handbuch d. ärztl. Erfahrugen im Weltkriege, by Otto Vosz und G. Killian, 1914/1918, Bd. VI. 1921, p. 111. p. 169, p. 305, Bd. I, p. 15, Bd. II. 11. Lehrbuch d. Ohrenheilk. by Jakobson and Blan, 1902, p. 1,

10. Handbuch d. Ohrenheilk. by Schwarze, 1892, p. 43, 12. Praktische Ohrenheilk. f. Aerzte, by Jansen and Kobrak, 1918, p. 1.
p. 153.
Lehrbuch d. Ohrenheilk. by Ostmann, 1909. 15. Allg. Chirurgie by Lexer, 1920, p. 100, p. 101, p. 104. Bd. IT. , 16. Kriegschirurgie, by Borchard and Schneiden 1917, p. 212. 17. Enzyklopedie d. kl. Medizin. 1915. 18. Handbuch d. Baneologie by Dietrich, 1924

19. Diseases of the Ear by Buck 1898, p. 101.

20. Diseases of the Nose, Throat and Ear by Ballenger, 1914, p. 657. menseki sokutei, by Otani Kunikichi, Tokyo Igakkaizasshi, Vol. 21.

21. Nippon shôni no taihyô- 